\title{
The Demand for State and Local Government Employees
}

\author{
By Ronald G. EhrenberG*
}

During the $1953-70$ period, state and local government employment grew faster than total employment, rising from 8.6 percent to 14.0 percent of total employment on payrolls of nonagricultural establishments. While much of the rise was due to the growth of educational employment (145 percent), state and local noneducational employment also grew significantly faster ( 79 percent) than employment in the private nonagricultural economy (33 percent). Indeed, several noneducational employment categories have grown at rates approaching or exceeding that of educational employment in recent years (Table 1). By 1980, state and local government employment is projected by the Bureau of Labor Statistics to increase further to 15.9 percent of total nonagricultural payroll employment. ${ }^{1}$

Interest in the determinants of the level of such employment within a state and its allocation across functional categories is more than academic. Recently, fears have been expressed that the growing strength of public employee unions, their increased militancy, and the trend toward collective bargaining rights with respect to wage issues, will lead to inflationary wage increases in the sector and aggravate the

\footnotetext{
* Associate professor of economics, University of Massachusetts. Without implicating them for what remains, I am grateful to Orley Ashenfelter, James Kindahl, a referee, and the editor for their comments on earlier versions of the paper. The research was supported by a faculty research grant from the Manpower Administration, U.S. Department of Labor and the material presented here draws from my larger study (1972), prepared for that organization.

${ }^{1}$ See Manpower Report, Tables C-1, E-11; Handbook of Labor Statistics, Tables 38, 100; Public Employment (various issues).
}

financial problems facing state and local governments. ${ }^{2}$ These fears are explicitly based upon the assumption that public services are essential and consequently that the demand for public employees is wage inelastic. To many, the logical conclusion then drawn is that limitations should be placed on the collective bargaining rights of these groups. ${ }^{3}$

To date, however, no estimates have been presented of the wage elasticities of demand for public employees and consequently no quantitative discussion of the strength of the market forces, which might prevent such increases, has occurred. To the extent that state and local government employee unions value both the wage and employment levels of their members, high wage elasticities coupled with projected relatively slower rates of growth of employment demand would help to moderate the size of wage increases which they will seek in the future.

One can easily think of possibilities for substituting capital for labor in the provision of public services (for example, police patrol cars) and for substituting private for public provision (for example, private security agencies). Moreover, given the limited resources which state and local

\footnotetext{
2 Harry Cohany and Lucretia Dewey, Sheila White' and Sheila Weissbror present descriptions of these trends. Table 1 presents data which indicate that both over the 1961-70 and 1965-70 periods, state and local government employees' wages have increased more rapidly than wages in the private sector. However, as suggested by the editor, the past relative inflation of public employees' wages was probably due to the rapid growth of employment demand in the sector and unrelated to the wage elasticities of demand

${ }^{3}$ See, for example, Harry Wellington and Ralph Winter.
} 
Table 1-Total Percentage Changes Full-Time Equivalent State and Local Government Employment and Monthly Payroll Per Man, by Function

\begin{tabular}{|c|c|c|c|c|}
\hline \multirow[b]{2}{*}{ Category } & \multicolumn{2}{|c|}{ Employment } & \multicolumn{2}{|c|}{ Payroll Per Man } \\
\hline & $1965-70$ & $1961-70$ & $1965-70$ & $1961-70$ \\
\hline Education & 27.6 & 60.5 & 41.8 & 66.5 \\
\hline Highway & 3.4 & 10.6 & 38.5 & 61.6 \\
\hline Public Welfare & 47.1 & 99.5 & 41.6 & 68.2 \\
\hline Hospitals & 18.6 & 38.3 & 51.4 & 74.4 \\
\hline Health & 36.0 & 55.3 & 43.6 & 68.6 \\
\hline Police & 29.0 & 44.9 & 43.0 & 75.8 \\
\hline Fire Protection & 12.1 & 18.4 & 47.7 & 74.9 \\
\hline Sewerage & 10.9 & 26.4 & 37.4 & 59.0 \\
\hline Other Sanitation & 11.4 & 17.9 & 37.7 & 59.6 \\
\hline Parks and Recreation & 17.2 & 29.8 & 34.4 & 56.7 \\
\hline Natural Resources & 12.6 & 23.6 & 41.2 & 65.3 \\
\hline Correction & 28.0 & 54.6 & 44.9 & 76.6 \\
\hline Libraries & 9.9 & N.A. & 42.2 & N.A. \\
\hline \multicolumn{5}{|l|}{ Employment Security } \\
\hline Administration & 18.0 & N.A. & 33.6 & N.A. \\
\hline Financial Administration & 12.6 & 19.0 & 41.1 & 61.3 \\
\hline General Control & 31.6 & 45.4 & 38.2 & 62.8 \\
\hline Local Utilities & 7.0 & 14.8 & 38.0 & 76.2 \\
\hline Private-Nonfarm & 14.2 & 27.9 & 31.4 & 50.5 \\
\hline Private-Manufacturing & 7.4 & 18.8 & 28.7 & 44.8 \\
\hline
\end{tabular}

Source: Derived from data found in various issues of Public Employment and Handbook of Labor Statistics. The private figures are percentage changes in total payroll employment and average hourly earnings of nonsupervisory employees.

governments can command, an increase in the relative price of a public service should lead to a substitution against that service. Thus, it is not obvious, a priori, that the wage elasticities of demand for all categories of state and local government employees are inelastic.

The primary purpose of this paper is to present empirical estimates of the wage elasticities of demand for different categories of state and local government employees. The employment demand equations that are estimated are derived from a utility maximization model of state and local government behavior. After presenting this model in the first section, we next briefly discuss the data used in the study. The structural system of demand equations is then estimated using pooled timeseries and cross-section information, with annual individual state data as the units of observation. A number of alternative estimation methods are used in the analysis. Parameter estimates obtained from the model are utilized in the final section to simulate the disemployment effects of postulated future relative wage increases for individual classes of state and local government employees, as well as increases for all classes relative to the private sector.

Our estimates indicate that statistically significant negative wage elasticities of demand exist for almost all functional categories of state and local government employees. However, these elasticities do appear to be inelastic and consequently the simulated disemployment effects are quite small. Thus, while there is evidence that state and local government decision makers respond to market forces in choosing their employment portfolios, these responses do not appear to be sufficiently 
strong to limit the size of real wage increases which state and local government employees may seek in the future.

\section{Theoretical Structure}

Abstracting from the myriad of state and local government bodies within a state, we consider a single decision-making unit which is assumed to determine the allocation of state resources between public and private production and also the per capita level and functional distribution of state and local government employment. Employing a "utility-tree" approach, let the utility function of this unit be written as

(1) $U=$

$U\left[V^{A}\left[\begin{array}{l}\text { privately } \\ \text { produced } \\ \text { goods and } \\ \text { services }\end{array}\right], V^{B}\left[\begin{array}{l}\text { publicly } \\ \text { produced } \\ \text { goods and } \\ \text { services }\end{array}\right]\right]$

The decision-making body is assumed to derive utility from the various categories of public services, with the per capita service flow from each category being proportional to the per capita category employment level. At each point in time, for any function, the factor of proportion is assumed constant across states. Hence, we are implicitly assuming no quality differentials within an employment category across states and, since state price indices for the "cost of capital" do not exist, we have also ignored the possibility of substituting capital for labor.

Specifically, suppose that the branch utility function $\left(V^{B}\right)$ is of the form, ${ }^{4}$

A specific member of this class of utility functions is the Stone-Geary utility function,

$$
U(M)=\sum_{k=1}^{n} a_{k} \log \left(\frac{M_{k}}{P}-\frac{b_{k}}{P}\right), \quad a_{k}>0, \quad \sum_{k=1}^{n} a_{k}=1
$$

Richard Stone, Richard Parks, and Robert Pollack and Terrance Wales utilize this utility function to derive and estimate consumer demand functions.

$$
\begin{aligned}
& V^{B}=V^{B}\left[\frac{M_{1}}{P}-\frac{b_{1}}{P}, \frac{M_{2}}{P}-\frac{b_{2}}{P}, \ldots,\right. \\
& \left.\qquad \frac{M_{n}}{P}-\frac{b_{n}}{P}\right] \\
& M_{j}>b_{j} \text { for all } j
\end{aligned}
$$

Here, $M_{k}$ is the full-time equivalent state and local government employment level of the $k$ th functional category, $b_{k}$ is the minimum required number of type $k$ employees, $P$ is the state population, and there are $n$ functional employment categories.

The minimum required employment levels are introduced because state and local government decision making is often alleged to be conducted on an incremental basis, with previous departmental budgets or employment levels taken as given. ${ }^{5}$ To allow for this possibility we assume, in a manner analogous to that of Pollack and Wales, that the minimum required number of employees in a category is proportional to the lagged category employment level.

$$
\begin{aligned}
b_{k}=\alpha_{k} M_{k}^{i-1}, & 0 \leq \alpha_{k} \leq 1, \\
& k=1,2, \ldots, n
\end{aligned}
$$

Employment decisions are strictly incremental if the $\alpha_{k}$ are all unity, while the entire employment portfolio is a decision variable if all the $\alpha_{k}$ are zero. Intermediate values indicate that the category employment levels can be cut to some extent. An interpretation of (2) and (3) is then as follows: For any level of budgeted funds, the decision-making body first makes expenditures for the minimum required numbers of employees and then with the remaining budgeted funds, chooses the increments to these employment levels so as to maximize

\footnotetext{
s Ira Sharkansky and the references cited therein present evidence that agencies are seldom cut below their previous levels of appropriations. However this in itself is not evidence of incremental budgeting, for with growing state and local government budgets it is conceivable that the appropriate marginal conditions would dictate that all agencies be expanded anyway.
} 
the branch utility function $\left(V^{B}\right)$ which depends only on the per capita increments.

Suppose that the decision makers seek to maximize the "higher-level" utility function (1) subject to a constraint that involves total available resources in the state, here assumed to be a function of per capita personal income and per capita grants from the federal government, and the prices of the various individual publicly and privately produced services. If we further assume that the higher-level utility function is strongly separable, which requires that the marginal rates of substitution between different categories of public services be independent of "consumption" levels of privately produced services, then Robert Strotz has shown that the decision makers will optimally follow a two-stage process. ${ }^{6}$ First the expenditure levels for each aggregated branch (public vs. private) will be selected with the resources allocated to each branch being a function only of the total resources available and the aggregate branch price indices. Then expenditure levels for specific commodities, in either the public or private branch, will be determined as functions of the total own branch expenditure level and the specific prices of all commodities within the branch alone.

If we assume that the per capita total state and local government employment budget in a state is approximately proportional to the per capita "public branch allocation," the above suggests that it is reasonable to specify the per capita total employment budget $(B / P)$ as being determined by, ${ }^{7}$

\footnotetext{
- As we have already indicated in our introduction, the strong separability assumption is not strictly valid as many services produced in the public sector have viable private substitutes. Furthermore, privately produced but publicly purchased services would be included in branch $A$. Nevertheless, the assumption is useful in that it provides an analytic foundation for (4).

${ }^{7}$ Decision makers are viewed in (4) as having sufficient flexibility so that even grants tied to specific functions serve to increase the total employment budget,
}

$$
\begin{aligned}
\log (B / P) & =S_{0}+S_{1} \log (R W) \\
+ & S_{2} \log (G / P)+S_{3} \log (Y / P)
\end{aligned}
$$

Here $Y / P$ is per capita personal income, $G / P$ is per capita grants from the federal government to state and local governments in the state and $R W$ is a measure of the average relative cost of publicly produced to privately produced goods and services. For empirical purposes $R W$ is defined as the ratio of average monthly earnings of state and local government employees to the comparable figure for manufacturing production workers in the state.

Once the per capita total employment budget is determined, the decision makers choose the per capita level and functional distribution of state and local government employment by maximizing the branch utility function (2) subject to (3) and the constraint that the total employment budget be exhausted.

$$
\sum_{k=1}^{n} W_{k}\left(M_{k}-b_{k}\right)=B-\sum_{k=1}^{n} W_{k} b_{k}
$$

$W_{k}$ is the monthly payroll cost per employee of the $k$ th category. Assuming that the customary regularity conditions hold for (2), its maximization subject to (3) and (5) yields a general system of category employment demand equations.

$$
\text { (6) } \begin{array}{r}
\frac{M_{j}^{\mathrm{t}}}{P}-\frac{\alpha_{j} M_{j}^{t-1}}{P}=F\left(W_{1}, W_{2}, \ldots, W_{n},\right. \\
\left.\left(B-\sum_{k=1}^{n} W_{k} \alpha_{k} M_{k}^{\mathrm{t}-1}\right) / P\right) \\
j=1,2, \ldots, n
\end{array}
$$

In our empirical work (6) is approxi-

rather than only the specific category budget. Moreover, matching grants are assumed to have only income and not price effects. A long literature exists (for example, Edward Gramlich and David Smyth) which neither conclusively support nor refute these assumptions. Federal grants are also treated as being exogenous for our purposes. Our formulation is dictated by data considerations and the particular functional form is chosen for analytic convenience. 
mated by the following system of $\log$ linear employment demand equations. ${ }^{8}$

$$
\begin{aligned}
& \log \left(\frac{M_{j}^{\mathrm{t}}}{P}-\frac{\alpha_{j} M_{j}^{\mathrm{t}-1}}{P}\right)=b_{0 j}+b_{1 j} \log W_{j} \\
& +b_{2 j} \log \left(B-\sum_{k=1}^{n} W_{k} \alpha_{k} M_{k}^{\mathrm{t}-1}\right) / P \\
& +\sum_{R=1}^{m} c_{R} \log S D R \quad j=1,2, \ldots, n
\end{aligned}
$$

To avoid problems of severe multicollinearity, (7) excludes all wage variables except the employment category's own wage. Furthermore, since it is erroneous to specify that the relative importance of the various services are constant across states or within a state over time, the system includes as explanatory variables those sociodemographic variables $(S D R)$ that are expected to influence the decision makers' tastes for the various services. ${ }^{9} \mathrm{On}$ the basis of data availability and preliminary experimentation, the variables utilized are the state population density (SD1), the proportion of the state population ages 5-17 (SD2), and the proportion of the state population over age 65 (SD3). The system of $n+1$ equations contained in (4) and (7) is estimated in Section III. ${ }^{10}$

\footnotetext{
${ }^{8}$ The specific utility function found in fn. 4 leads directly to the system of demand equations in (7), with the further restrictions that $b_{1 j}=-1$ and $b_{2 j}=1$ for all $j$. Since we are primarily interested in ascertaining the magnitude of the wage and employment budget elasticities of demand, these restrictions are not imposed in the estimation and the specific functional form of the utility function is not assumed a priori. However, we emphasize that (7) must then be regarded only as an approximation to a true system of demand equations.

Note that if government employers face positively sloped labor supply curves, the wage elasticities estimated from (7) will be biased in a positive direction. Orley Ashenfelter presents evidence, however, that the aggregate supply of labor to the state and local sector is highly elastic and thus this bias is likely to be small.

${ }^{9}$ For example, we would expect the age distribution of the population to effect the relative importance to the decision makers of educational employment. Similarly population density will influence the relative importance of police employment.
}

${ }^{10} \mathrm{I}$ also estimated a variant of (7) which substituted

\section{The Data}

Published data allow us to consider eleven functional categories of employees and to pool time-series and cross-section information, with annual individual state data during the 1958-69 period as the units of observation. ${ }^{11}$ Full-time equivalent state and local government employment has been reported by function and state since 1953, however the number of functional categories reported declined gradually from nineteen in 1969 to ten in 1953. Thus increasing the length of the time period under consideration can be done only at the expense of aggregating categories.

The choice of 1958 as the initial year was made on pragmatic grounds; by the availability of data on per capita federal grants to state and local governments. Referring to Table 1 , this required that sewerage and other sanitation employment be aggregated into a sanitation category and financial administration employment be included with general control. Due to the similarity of functions performed by the two categories in each of these aggregate groups there appeared to be obvious reporting errors over time within several states (for example, the ratio of financial administration to general control employment in a state fluctuated widely over time, while the total of the two and their relative wage remained fairly constant). Hence both of these aggregations appeared to be desirable on a priori grounds. Finally, I constructed a miscellaneous all others category that included parks and recreation, correction, library, employment se-

the category wage relative to the average wage for all state and local government employees in the state $\left(W_{j} / W_{T}\right)$ for the category own wage $\left(W_{j}\right)$. The estimates were similar in nature to those obtained using specification (7) and are omitted here for brevity. See Ehrenberg, chs. 4 and 5.

11 The variables used in the study are constructed from published data found in the U.S. government publications which are listed in the references. 
curity administration, local utility, state liquor store, and all other state and local government employees not explicitly contained in any of the categories listed in Table $1 .{ }^{12}$

All of the variables expressible in dollar terms were deflated by the national consumer price index to obtain real values; unfortunately no individual state price indices exist and we were unable to control for interstate price differences. The average monthly payroll cost per man variable was derived by dividing full-time equivalent employment into total monthly payroll. In 1964 the reported full-time equivalent employment variable was rounded to the nearest 100 employees, which induced large errors in the wage variable for small states and/or relatively small functional employment categories. Consequently, data from 1964 was eliminated from the sample. Finally, no data was reported for Alaska or Hawaii in 1958 and 1959. The final sample thus consists of 546 state-year observations.

\section{Empirical Estimates}

This section presents estimates of the demand for state and local government employees. We first briefly discuss estimates of the derived reduced form model, when the minimum required employment level for each class is assumed to be zero, and consider the legitimacy of aggregating the data across years. Maintaining the same assumption, we next present estimates of the structural model utilizing the pooled data. Finally, the incremental budgeting model is estimated under a restrictive set of assumptions.

\footnotetext{
${ }^{12}$ For a description of the type of functions performed by employees in each category and an attempt to use a clustering procedure to determine the appropriate aggregated groups, see Ehrenberg, ch. 3. A more complete description of the methods of, and problems involved in constructing the variables utilized in the study is also found there.
}

\section{Estimates of the Reduced Form and Tests for Aggregation Bias}

Initially we assume that the minimum required employment level for each class of employees is zero; that the decision maker is free to choose the entire employment portfolio each period. Substituting (4) into (7) yields the reduced form system of demand equations. This system was estimated in three different ways by ordinary least squares: First, separately for each year in the sample using cross-section data. Second, using the pooled data for all years. Third, using the pooled data with a set of zero-one dummy variables included to allow the intercept term to vary over time. $^{13}$

In general, the estimated coefficients of the economic variables in the individual year cross-sections, especially the wage elasticities, were statistically insignificant. In those cases that a particular coefficient was significant, it tended to vary widely across years. This clearly points out the dangers inherent in drawing conclusions from a single year's cross-section study.

As expected the estimates based upon the pooled data were vastly superior in terms of the signs and statistical signifcance of the key economic variables. ${ }^{14}$ However one may question the legitimacy of aggregating the data across years. Using the sum of squared residuals obtained from the individual year and pooled regressions; $F$-statistics were calculated to test for the possibility of aggregation bias. ${ }^{15}$ Specifi-

\footnotetext{
${ }_{13}$ The intercept dummy variables are included to capture intertemporal productivity variations, since if the productivity of state and local government employees varies over time, the demand for each category will also vary, ceteris paribus. Inasmuch as their inclusion did not significantly alter the estimated wage elasticities of demand, the intercept shift variables are not utilized in the subsequent analysis.

${ }_{14}$ For brevity, these estimates are not presented here since an analysis of them would be quite similar to that of the structural estimates.

${ }^{16}$ See Frank Fisher.
} 
cally we consider tẉo null hypotheses here:

(1) That the entire set of reduced form coefficients is identical across years for each category.

(2) That the entire set of reduced form coefficients except the intercept is identical across years for each category.

For six of the eleven functional categories the null hypothesis that the entire set of reduced form coefficients is equal across years was rejected. Furthermore, the rejection was not due solely to the intercept term varying; in four of these six cases null hypothesis (2) was also rejected.

For pragmatic reasons once again, we will continue to utilize the pooled data in what follows. However, our results must be qualified by noting that for about half of the categories information will be lost by the aggregation. Our simulations in the next section will be based in these cases upon estimated average elasticities which may differ from the marginal elasticities which we would obtain if significant coefficients could be derived from the individual year cross-section regressions.

\section{Structural Estimates- No Incremental Budgeting}

To estimate the structural model, we first estimate (4) to obtain an estimated per capita total employment budget $(\hat{B} / P)$ and then use this as an instrumental variable in the estimation of (7). Moreover, if the employment budget is fixed, a positive residual in spending for one functional category must be offset by a negative residual in some other category. Due to the contemporaneous correlation of residuals across equations in (7), one would expect three-stage least squares estimates $(3 S L S)$ to be asymptotically more efficient than two-stage least squares estimates and the former method is used below. ${ }^{16}$

\footnotetext{
${ }^{16}$ Two-stage least squares estimates of (7) differed only marginally.
}

Utilizing the pooled data, estimation of (4) yielded the following (where the numbers in parentheses are absolute $t$-values).

$$
\begin{aligned}
\log (B / P)= & -4.120+.315 \log (R W) \\
& (21.48)(7.87) \\
& +.222 \log (G / P) \\
& (17.32) \\
& +.753 \log (Y / P) \\
& (28.60)
\end{aligned}
$$

$$
R^{2}=.754
$$

The less than unitary elasticity for $R W$ indicates that, ceteris paribus, an increase in the average wage of public employees relative to private sector wages will cause a disemployment impact as the per capita total employment budget would increase by a smaller percentage. As indicated in Section IV, however, this impact may be partially offset if the resulting adjustments in the labor market lead to an increase in per capita income. Furthermore, to simulate the estimated impact on each category's employment level, requires estimation of the complete system.

The $3 S L S$ estimates of (7) obtained under the assumption that the minimum required employment levels are all zero, are presented in Table $2 .{ }^{17}$ The own wage elasticities are negative and statistically significant in all cases, save for the miscellaneous all other category. ${ }^{18}$ Except for the public welfare category these elasticities are all significantly less than unity. Thus, as conjectured by many, the partial wage elasticities of demand for public employees do appear to be primarily inelastic. ${ }^{19}$ Note however, that even the "essential services" police and fire protection have significant,

${ }_{17}$ The standard errors of these estimates are asymptotic estimates, hence the 1 -tests are only asymptotically valid and should be interpreted heuristically.

18 Given the heterogeneous nature of the functions performed by employees in the latter category, the insignificant elasticity is not unexpected.

${ }^{19}$ They are partial elasticities because they do not consider the impact on the employment budget equation of an increase in a category's wage. 
Tarle 2-3SLS Estimates-Pooled Data

Log-Linear EQuations

\begin{tabular}{|c|c|c|c|c|c|}
\hline $\begin{array}{c}\text { Dependent variable } \\
\qquad\left(M_{j} / P\right)\end{array}$ & $W_{j}$ & $(\hat{B} / P)$ & $S D 1$ & $S D 2$ & $S D 3$ \\
\hline Education & $\begin{array}{l}-.425 \\
(8.89)^{\mathrm{b}}\end{array}$ & $\begin{array}{r}.730 \\
(16.61)\end{array}$ & $\begin{array}{l}-.055 \\
(10.98)\end{array}$ & $\begin{array}{r}.183 \\
(3.95)\end{array}$ & \\
\hline Highway & $\begin{array}{r}-.594 \\
(11.55)\end{array}$ & $\begin{array}{r}.441 \\
(8.04)\end{array}$ & $\begin{array}{c}-.160 \\
(27.48)\end{array}$ & & \\
\hline Public Welfare & $\begin{array}{l}-1.001 \\
(10.58)\end{array}$ & $\begin{array}{r}1.569 \\
(19.25)\end{array}$ & $\begin{array}{r}.029 \\
(2.93)\end{array}$ & & $\begin{array}{r}.289 \\
(6.72)\end{array}$ \\
\hline Hospital & $\begin{array}{l}-.410 \\
(9.86)\end{array}$ & $\begin{array}{r}.571 \\
(7.87)\end{array}$ & $\begin{array}{l}.058 \\
(5.64)\end{array}$ & & $\begin{array}{r}.353 \\
(8.67)\end{array}$ \\
\hline Health & $\begin{array}{l}-.279 \\
(4.08)\end{array}$ & $\begin{array}{r}.684 \\
(9.06)\end{array}$ & & & $\begin{array}{l}-.361 \\
(9.88)\end{array}$ \\
\hline Police & $\begin{array}{l}-.281 \\
(5.73)\end{array}$ & $\begin{array}{r}.795 \\
(16.08)\end{array}$ & $\begin{array}{l}.064 \\
(11.35)\end{array}$ & & \\
\hline Fire & $\frac{-.277}{(5.65)}$ & $\begin{array}{r}.850 \\
(12.95)\end{array}$ & $\begin{array}{r}.133 \\
(15.39)\end{array}$ & & \\
\hline Sanitation & $\begin{array}{l}-.504 \\
(7.55)\end{array}$ & $\begin{array}{r}.593 \\
(6.45)\end{array}$ & $\begin{array}{r}.141 \\
(12.25)\end{array}$ & & \\
\hline Natural Resources & $\begin{array}{l}-.530 \\
(5.76)\end{array}$ & $\begin{array}{r}.282 \\
(3.19)\end{array}$ & $\begin{array}{l}-.334 \\
(36.21)\end{array}$ & & \\
\hline General Control & $\begin{array}{l}-.316 \\
(7.49)\end{array}$ & $\begin{array}{r}.820 \\
(19.53)\end{array}$ & $\begin{array}{l}-.072 \\
(14.23)\end{array}$ & & \\
\hline All Other & $\begin{array}{r}.067 \\
(1.18)\end{array}$ & $\begin{array}{r}.740 \\
(12.68)\end{array}$ & $\begin{array}{r}.008 \\
(1.16)\end{array}$ & & \\
\hline
\end{tabular}

Notes: $M_{j} / P=$ per capita full-time equivalent state and local government employees of category $j$.

$G / P=$ per capita federal grants to state and local governments, in real terms.

$Y / P=$ per capita personal income in real terms.

$B / P=$ per capita total employment budget for state and local government employees, in real terms.

$W_{j}=$ average monthly payroll cost per full-time employee in category $j$, in real terms.

$R W=$ ratio of average monthly payroll cost per man of all full-time state and local government employees to average monthly earnings of manufacturing production workers.

$S D 1=$ population density

$S D 2=$ proportion of the population ages 5-17.

$S D 3=$ proportion of the population, age 65 and up.

Sources: Derived from data in U.S. Bureau of Census, Estimales of the Population of States by Age, CRP Series P-25 (various issues); Government Finances (various issues); Public Employment (various issues); Statistical Abstract of the United States, 1969; Handbook of Labor Statistics 1970; Survey of Current Business (Apr. 1965, Apr. 1970).

- The number of state-year observations for all equations is 546; 11 years (1958-63, 65-69) times 50 states minus the observations for Alaska and Hawaii in 1958 and 1959.

b Absolute $t$-values are shown in parentheses. 
although small, wage elasticities of demand. The estimates of the per capita employment budget elasticities are all positive and statistically significant.

With respect to the sociodemographic variables, population density appears to be negatively related to education, highway, natural resource, and general control employment. The latter relationship may reflect the substitution of capital for labor that is possible in large scale clerical and administrative operations. This variable is also positively related to public welfare, hospital, police, fire, and sanitation employment. Several plausible factors relating to the relationship between population density and the costs and benefits from these services may explain the signs of these coefficients.

As expected, the proportion of the population between the ages of 5 and 17 is positively related to educational employment and the proportion of the population older than age 65 is positively related to public welfare and hospital employment. The negative relationship between the proportion of the population older than age 65 and health employment may be due to the preventive nature of many of the services in this category (for example, school immunization programs); services which are not directed primarily at the aged..$^{20}$

\footnotetext{
${ }^{20}$ Two extensions of the analysis that were conducted warrant brief reporting: First, regardless of whether state and local government decision making is actually governed by an explicit utility maximization framework, it seems desirable to use an econometric approach in which the sum of the estimated payroll expenditures across categories adds up to the estimated total employment budget. This can be expressed as the Engel aggregation condition, that the sum of the per capita employment budget $(B / P)$ elasticities of demand, weighted by their respective category proportions of total payroll expenditures, be unity. Formal $F$-tests of this restriction for the estimates of (7) reported in Table 2, utilizing 1969 national average category expenditure weights, indicated that the weighted sum was significantly less than unity. Consequently, the system (7) was reestimated using a restricted $3 S L S$ technique (see Henri Theil), with the Engel aggregation condition imposed as a constraint. The restricted wage elasticities
}

\section{Structural Estimates- Incremental Budgeting}

To identify the $\alpha_{k}$ coefficients that appear in (7) requires either a method which allows non-linear constraints to be placed on parameters across equations or an iterative procedure. Software limitations prevented the former and to iterate over eleven coefficients searching for maximum-likelihood sets of estimates would have proven prohibitively expensive. Consequently, we adopt a second best procedure and assume that the minimum required proportion of last period's per capita employment level $\left(\alpha_{k}\right)$ is the same for all functions $(\alpha)$. While this assumption might be justified by arguing that all agencies apply equal pressure on decision makers to preserve their sizes, its main justification is in its analytic convenience.

Because the system (7) is log-linear, one cannot shift the $\left(\alpha M_{1}^{\mathrm{t}-1} / P\right)$ variable in each equation to the right-hand side and thus the dependent variable will vary as $\alpha$ varies. Hence, we were unable to follow a procedure similar to that used by other investigators, of choosing the value of $\alpha$ which minimizes the sum of squared residuals in (7) across all eleven equations,

of demand differed only marginally from the unrestricted estimates, except the elasticity for educational employment which doubled in magnitude. The employment budget elasticity for education also increased substantially; intuitively this was expected to occur as the expenditure weight on education is over 50 percent. The employment budget elasticities for the other categories increased only marginally.

Second, the dangers inherent in inferring time-series responses from pooled cross-section time-series data are well known. While the lack of degrees of freedom generally led to statistically insignificant coefficients when the system (4), (7) was estimated separately for each individual state using the short time-series 1958-63, 65-69; these statistically insignificant individual state time-series coefficients were used to perform nonparametric tests to ascertain if the wage elasticities of demand for each category appeared to be "primarily" negative as postulated. Such tests (Ehrenberg, ch. 4) supported this hypothesis for most of the categories. See Alexander Mood and Franklin Graybill, p. 403-25 for the basis of the nonparametric test used. 
TAble 3-3SLS Estimates-InCRemental Budgeting Model ${ }^{\mathrm{a}}$ Log-Linear Equations $\alpha=.5$

\begin{tabular}{|c|c|c|c|c|c|}
\hline $\begin{array}{l}\text { Dependent variable } \\
\left(M_{j}^{t} / P\right)-.5\left(M_{i}^{t-1} / P\right)\end{array}$ & $W_{j}$ & $(\hat{B} / P)^{\mathrm{b}}$ & $S D 1$ & $S D 2$ & $S D 3$ \\
\hline Education & $\begin{array}{l}-.175 \\
(3.15)^{\circ}\end{array}$ & $\begin{array}{r}.037 \\
(6.01)\end{array}$ & $\begin{array}{l}-.085 \\
(11.09)\end{array}$ & $\begin{array}{l}.170 \\
(2.43)\end{array}$ & \\
\hline Highway & $\begin{array}{c}-.635 \\
(14.23)\end{array}$ & $\begin{array}{r}.394 \\
(8.02)\end{array}$ & $\frac{-.176}{(25.54)}$ & & \\
\hline Public Welfare & $\begin{array}{l}-.338 \\
(3.65)\end{array}$ & $\begin{array}{r}.888 \\
(10.49)\end{array}$ & $\begin{array}{c}-.008 \\
(.64)\end{array}$ & & $\begin{array}{r}.452 \\
(7.98)\end{array}$ \\
\hline Hospital & $\frac{-.516}{(7.42)}$ & $\begin{array}{r}.223 \\
(2.41)\end{array}$ & $\begin{array}{r}.038 \\
(2.80)\end{array}$ & & $\begin{array}{r}.379 \\
(6.74)\end{array}$ \\
\hline Health & $\begin{array}{l}-.300 \\
(4.27)\end{array}$ & $\begin{array}{l}.608 \\
(7.56)\end{array}$ & & & $\begin{array}{l}-.405 \\
(8.29)\end{array}$ \\
\hline Police & $\begin{array}{r}-.023 \\
(.45)\end{array}$ & $\begin{array}{l}.451 \\
(8.23)\end{array}$ & $\begin{array}{l}.028 \\
(3.77)\end{array}$ & & \\
\hline Fire & $\begin{array}{l}-.240 \\
(3.37)\end{array}$ & $\begin{array}{l}.638 \\
(8.11)\end{array}$ & $\begin{array}{l}.098 \\
(8.59)\end{array}$ & & \\
\hline Sanitation & $\begin{array}{l}-.539 \\
(7.54)\end{array}$ & $\begin{array}{l}.239 \\
(2.49)\end{array}$ & $\begin{array}{l}.131 \\
(9.56)\end{array}$ & & \\
\hline Natural Resources & $\begin{array}{l}-.602 \\
(6.37)\end{array}$ & $\begin{array}{l}.278 \\
(3.12)\end{array}$ & $\frac{-.343}{(28.57)}$ & & \\
\hline General Control & $\begin{array}{l}-.099 \\
(1.64)\end{array}$ & $\begin{array}{r}.480 \\
(8.32)\end{array}$ & $\frac{-.101}{(12.36)}$ & & \\
\hline All Others & $\begin{array}{r}.261 \\
(4.39)\end{array}$ & $\begin{array}{r}.320 \\
(4.68)\end{array}$ & $\begin{array}{l}-.023 \\
(2.41)\end{array}$ & & \\
\hline
\end{tabular}

a For number of observations, sources of data, and definitions, see Table 2.

b In this table $(\hat{B} / P)$ is used as a short-hand notation for

$$
(\hat{B} / P)-.5 \sum_{j=1}^{11} W_{j}\left(M_{j}^{\mathrm{t}-1} / P\right)
$$

c Absolute $t$-values in parentheses.

time periods and states. ${ }^{21}$ Rather, $3 S L S$ estimates of the system were derived for a set of values of $\alpha$ and it was heuristically determined that the minimum required proportion $(\alpha)$ lies in the range 0.0 to $0.5 .^{22}$ For values of $\alpha$ which fall in this range, disemployment effects of postulated future relative wage increases are simulated in the next section. Since these estimates are tolerably stable over the range

\footnotetext{
${ }^{21}$ See, for example, Stone.
}

of values, it is unnecessary for us to choose a "statistically optimal" estimate for $\alpha$. For comparison purposes, estimates of (7) when $\alpha$ was assumed to equal .5, are presented in Table $3 .{ }^{23}$ In general as $\alpha$ increased from 0 to .5 , the employment budget elasticities decreased; however, there was no uniform pattern of change for the own wage coefficients.

\footnotetext{
${ }^{22}$ The system (7) was estimated as $\alpha$ varied from 0.0 to 0.9 in steps of 0.1 . Two criteria were used in our
} 


\section{Implications For Public Policy}

The impact on per capita full-time equivalent state and local government employment in each functional category of an increase in the category real wage can be simulated using the parameter estimates described in the previous section. We consider two cases here:24

$A$. The real wage of a functional category of state and local government employees increases relative to all other employees' real wages and nonlabor real personal income.

$B$. The real wages of all state and local government employees increase proportionately, relative to all other employees' real wages and nonlabor real personal income.

For both cases, we calculate the total own wage elasticity of demand for each functional employment category, which consists of two components. First, the direct partial elasticity, based upon the estimated own wage $\left(W_{j}\right)$ elasticities obtained from the individual category employment demand equations. Second, the indirect effect, which operates through the impacts of an increase in the class wage on the relative cost of publicly to privately produced services $(R W)$ and on per capita personal income $(Y / P)$ in the per capita total employment budget equation. Since the per capita total employment budget $(B / P)$ tends to increase due to these im-

heuristic evaluation of which values of $\alpha$ yielded plausible estimates. First, as observations were eliminated from the sample when $M_{j} / P-\alpha M_{j}^{t-1} / P$ was negative for any category, what proportion of the original number of observations remained in the sample for each value of $\alpha$ ? Second, for each value, what proportion of the wage and employment budget elasticities were statistically significant and of the anticipated sign? Details of this analysis are also found in Ehrenberg, ch. 4.

${ }^{23}$ It is easily seen that $b_{1 j}$ and $b_{2 j}$ in (7) represent the steady-state wage and employment budget elasticities, respectively.

${ }^{24}$ Several additional cases are considered in Ehrenberg, ch. 5 . pacts, as long as an employment category has a positive employment budget elasticity, its total wage elasticity will be smaller in absolute value than the partial elasticity. ${ }^{25}$ Moreover, ceteris paribus, the larger the partial wage elasticity, the smaller the employment budget elasticity, and the smaller the share of the total employment payroll spent on the category, the larger in absolute value will be the total wage elasticity. Hence, the larger will be the disemployment impact that would result from an increase in the class wage.

Differentiating the system (4), (7) with respect to the real wage of each class, one can derive formulae for the total own wage elasticities of demand for the two cases considered. ${ }^{26}$ In addition to the parameter estimates obtained from the estimation of (4) and (7) these elasticities are seen to depend upon the fraction of the employment budget initially spent on each category, the proportion of personal income earned by state and local goverment employees, the ratio of per capita total state and local government employment lagged

\footnotetext{
25. An increase in state and local government employees' wages would lead to the following set of adjustments in the labor market; a decline in state and local government employment (the impact which we seek to estimate) and an increase in the level of unemployment and/or an increase in the supply of labor to the private sector, resulting in lower wages but greater employment there. To the extent that private'sector wages and employment do not change (perhaps due to wages which are inflexible in a downward direction), per capita personal income would increase as long as the demand for state and local government employees is wage inelastic. Our simulations ignore the adjustments that would occur in private sector wages and employment (i.e., they assume a private sector wage elasticity of unity), and may to a minor degree overstate the impact of public employee wage changes on per capita personal income. As a consequence, the total elasticities presented in Table 4 may be slightly biased towards zero. However, since the partial elasticities provide an absolute upper bound for the total elasticities, our main conclusions would be unaltered. The simulations also assume that per capita federal grants are unrelated to state and local government employees' wages.

${ }^{26}$ The formulae and their derivations are available upon request from the author.
} 
one year to the current total, and the comparable ratio for per capita employment in each category. National average values for each of these variables in 1969 are used in the simulation.

Substitution of these values and the necessary parameter estimates obtained from the estimation of (4) and (7) into the derived formulae, yields empirical estimates of the total own wage elasticities of demand. These are calculated for seven different sets of estimates of (7). ${ }^{27}$ In Table 4, for each functional category and case, we indicate the interval over which the seven sets of estimates varied. It should be emphasized that these do not represent 'statistical confidence intervals, rather they indicate only the sensitivity of the total elasticities to the value of $\alpha$ utilized. The short-run elasticities reported in Table 4 refer to the impact in the first year, while the long-run elasticities indicate the steady-state solutions. The two are identical when $\alpha=0$.

Considering first case $A$, in which employees in a functional category succeed in pushing up their real wages relative to all other employees and nonlabor personal income, the estimates appear to be tolerably stable for each category, except education and public welfare. Moreover in all cases, save perhaps public welfare, there is no doubt that the total own wage elasticities are inelastic. A 5 percent increase in the real wage of a class would, ceteris paribus, decrease per capita fulltime equivalent in the class by less than 5 percent. Furthermore, since population growth has averaged more than 1 percent a year, the category decline in total fulltime-equivalent employment would be even smaller.

Due to the fact that an increase in any

27 These estimates correspond to values of $\alpha$ assumed equal to 0 (Table 2), 0-restricted estimates, .1, .2, .3, and .4 (all not presented here for brevity), and .5 (Table 3).
Table 4-Disemployment Impact Simulations:

Interval Estimates of Total OWN Wage Elasticities

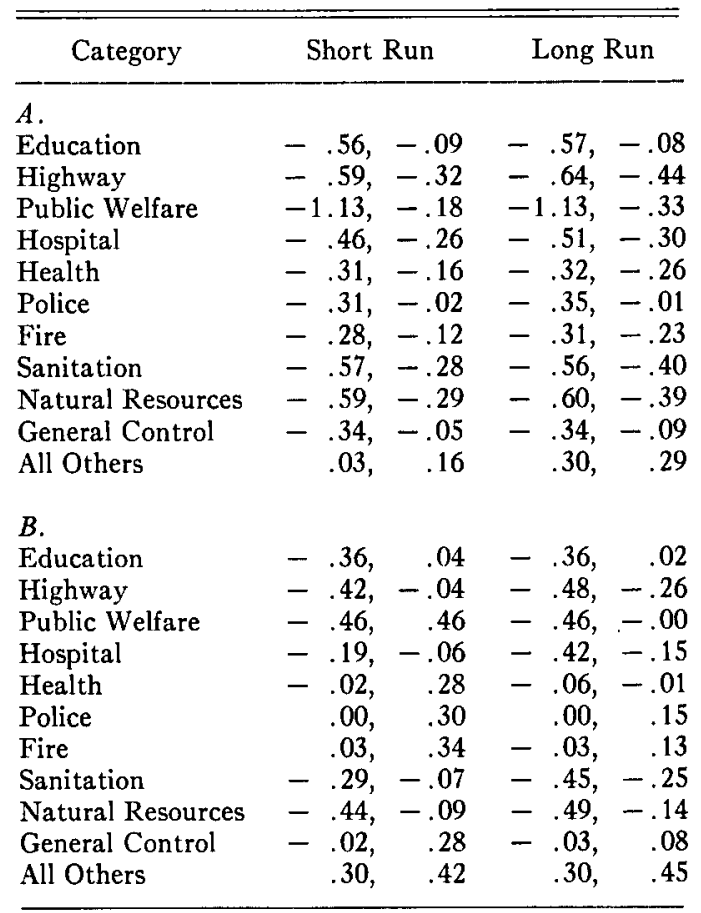

class wage increases the sum of the committed employment expenditures, all partial cross-wage elasticities of demand are negative in the short-run for case $A$. However, in most cases the magnitudes of these partial cross wage-elasticities are extremely small, often less than $-.001 .^{28}$ Furthermore, when we consider the indirect impacts through the total employment budget equation, the short-run total cross-wage elasticities are seen to be primarily positive and in the long-run they are all positive.

Turning to case $B$, in which all state and local government employees' real wages increase proportionately relative to all other employees' wages and nonlabor personal income, the estimated disem-

\footnotetext{
${ }^{28}$ For example, when $\alpha=.5$, only 6 of 110 partial cross-wage elasticities of demand were greater than .1 in absolute value with all referring to employment responses to changes in the education wage.
} 
ployment effects are now all smaller. Inasmuch as a proportionate state and local government employee wage increase removes the incentive to substitute across functional categories, this result was exexpected. Those elasticities that remain negative are all inelastic; however, several of the intervals now contain zero and a few of the estimated elasticities are even always positive. For example, in the long run, police, fire, general control, and the miscellaneous all other category, all appear to have positive total wage elasticities of demand.

These results suggest that while state and local governments do respond to market forces in choosing their employment portfolios, these market forces do not appear to be sufficiently strong to limit the size of real wage increases which state and local government employees may seek in the future. They also suggest that employees in each functional category have a stake in the economic well-being of members of all the other categories, as each category can minimize the potential employment losses of their members by seeking to increase the real wages of all categories, rather than merely their own real wage. Consequently, continual careful consideration, on both sides, should be given to the evolving structure of collective bargaining in this sector. ${ }^{29}$

\section{REFERENCES}

O. Ashenfelter, "Demand and Supply Functions for State and Local Government Employment: Implications for Public Employment Programs," unpublished paper, Princeton, Mar. 1972.

\footnotetext{
${ }^{29}$ The estimates of (4) and (7) can also be used to simulate the impact of public sector employment programs (such as that contained in the Emergency Employment Act of 1971 ) in which the federal government makes cash grants to state and local governments in an attempt to increase the number of public sector jobs. Ehrenberg, ch. 5 , presents such a simulation.
}

H. Cohany and L. Dewey, "Union Membership Among Government Employees," Mon. Lab. Rev., July 1970, 93, 15-20.

R. Ehrenberg, The Demand for State and Local Government Employees: An Economic Analysis, Lexington 1972.

F. Fisher, "Tests of Equality Between Sets of Coefficients in Two Linear Regressions: An Expository Note," Econometrica, Mar. 1970, 38, 361-66.

E. Gramlich, "The Effect of Federal Grants on State-Local Expenditures": A Review of the Econometric Literature," Nat. Tax Assn. Proc., 1969, 62, 569-93.

A. Mood and F. Graybill, Introduction to the Theory of Statistics, 2d ed., New York 1963.

R. Parks, "Systems of Demand"Equations: An Empirical Comparison of Alternative Functional Forms," Econometrica, Oct. 1969, 37, 629--51.

R. Pollack and T. Wales, "Estimation of the Linear Expenditures System," Econometrica, Oct. 1969, 37, 611-28.

I. Sharkansky, Spending in the American States, Chicago 1968.

D. Smyth, "The Response of State and Local Governments to Federal Grants," Nat. Tax J., Sept. 1968, 21, 349-58.

R. Stone, "Linear Expenditure Systems and Demand Analysis: An Application to the Pattern of British Demand," Econ. J., Sept. 1954, 64, 511-27.

R. Strotz, "Empirical Implications of the Utility Tree," Econometrica, Apr. 1957, 25, 269-80.

H. Theil, Economic Forecasts and Policy, 2d ed., Amsterdam 1961.

S. Weissbror, "Changes in State Labor Laws in 1970," Mon. Lab. Rev., Jan. 1971, 94, 61-62.

H. Wellington and R. Winter, "The Limits of Collective Bargaining in Public Employment," Yale Law J., June 1969, 69, 110727.

S. White, "Work Stoppages of Government Employees," Mon. Lab. Rev., Dec. 1969, 92, 29-34.

A. Zellner, "An Efficient Method of Estimat- 
ing Seemingly Unrelated Regressions and Tests for Aggregation Bias," J. Amer. Statist. Assn., June 1962, 57, 348-68.

U.S. Bureau of the Census, Estimates of the Population of States by Age, Current Population Reports, Series P-25, various issues. issues.

Governmental Finances, various , Public Employment, various issues.
- Statistical Abstract of the United States, Washington 1969.

U.S. Bureau of Labor Statistics, Handbook of Labor Statistics 1970, Bull. 1666, Washington 1970.

U.S. Department of Commerce, Surv. Curr. Bus., Apr. 1965 and Apr. 1970.

U.S. Department of Labor, Manpower Report of the President-1971, Washington 1971. 
Copyright of American Economic Review is the property of American Economic Association and its content may not be copied or emailed to multiple sites or posted to a listserv without the copyright holder's express written permission. However, users may print, download, or email articles for individual use. 